\title{
Kata-kata Serapan Bahasa Belanda pada Bahasa Melayu-Manado (Kajian Morfologi dan Leksikologi)
}

\author{
Pingkan Luciawati Sompi \\ gthommes@gmail.com \\ Golda J. Tulung \\ Djeinnie Imbang \\ Pascasarjana \\ Universitas Sam Ratulangi
}

\begin{abstract}
This research Design entitled "Loanwords from Dutch on Manadonese Malay - a Study of Morphology and Lexicology"is a descriptive analysis. It tends to describe the words in Manadonese Malay, especially adopted words from Dutch. Loanwords or adopted words or borrowing words are words adopted by the speakers of one language from the source language. This is the process of speakers adopting words from a source language into their native language. The words simply come to be used by a speech community when they speak different language, in this case Manadonese Malay. Dutch is the language spoken by Dutch people, especially The Old Dutch who formerly used by Dutch colonialists in Indonesia. Manadonese Malay is spoken in the population of the city of Manado, Bitung, Tomohon, Minahasa districts and surrounding areas. It has similarities with the dialect in Central Sulawesi and Molluca. Most of the words in Manadonese Malay are almost the same in Indonesian, which is the Malay. It is only used for oral communication, there is no standard orthography/writing never ratified.

Keywords: Loanwords, Dutch Language and Manado-Malay Language.
\end{abstract}

\section{Pendahuluan}

Bahasa merupakan bagian yang penting dalam kehidupan manusia, dalam bentuk tulis dapat merupakan catatan dari pengetahuan yang didapat oleh umat manusia dari satu generasi ke generasi berikutnya sedangkan dalam bentuk lisan merupakan sarana komunikasi antar individu dalam suatu masyarakat.

Menurut fungsinya secara umum, bahasa adalah sebagai alat untuk berkomunikasi, dalam arti, alat untuk menyampaikan pikiran, gagasan, atau perasaan. Adapun fungsi lainnya, menurut Gorys Keraf, bahasa adalah suatu alat untuk mengekspresikan diri, alat komunikasi, untuk adaptasi dan integrasi serta yang terakhir fungsi bahasa adalah suatu alat yang berfungsi sebagai kontrol sosial.

Di dunia hampir tak ada suatu bangsa yang dapat terbebas secara penuh dari kontak terhadap bangsa lain. Oleh karena itu, wajar jika dari hasil kontak langsung ini, suatu bangsa dapat dengan mudah menyerap kebudayaan dari bangsa lain, tak terkecuali bahasanya. Penyerapan bahasa dan budaya ini biasanya didominasi oleh bahasa dan 
budaya yang bersumber dari bangsa yang dianggap maju peradabannya dalam hal ini menjajah atau menguasai bangsa yang dianggap Iemah. Hegemoni kebudayaan dan bahasa ini juga terjadi pula pada kebudayaan dan bahasa di Indonesia. Bahasa Indonesia adalah bahasa nasional yang dijadikan alat pemersatu semua bahasa daerah yang ada di negara Indonesia. Pengaruh kuat bahasa asing terhadap bahasa indonesia semakin terasa dengan semakin maraknya berbagai kata serapan bahasa asing yang digunakan dalam berbagai ragam bahasa Indonesia. Memang, dalam beberapa kasus yang berkaitan dengan bahasa, penggunaan suku kata asing menjadi alternatif yang menyenangkan karena selain konotasi dan kata itu memang sesuai dengan yang dimaksud oleh pengguna bahasa, penggunaan istilah asing ini juga dinilai lebih praktis dan efisien.

Bahasa asing yang diserap kedalam bahasa Indonesia, terasa lebih singkat jika dibandingkan dengan terjemahan bahasa Indonesianya, karena dengan mengunakan bahasa asing dapat mempermudah tercapaianya kesepakatan jika bahasa Indonesia terlalu banyak sinonimnya dan kosa kata/pembendaharaan kata bahasa Indonesia sangatlah sedikit jumlahnya.

Secara sederhana, definisi kata-kata serapan adalah kata-kata yang berasal dari bahasa asing atau bahasa daerah IaIu digunakan dalam bahasa asli. Menurut Abdul Chaer (Chaer, A. 2007), terdapat tiga macam cara sebuah kata diserap kedalam bahasa asli. Pertama, kata itu sudah lazim digunakan dalam bahasa asli, sehingga penggunaanya tidak dirasakan asing oleh pengguna bahasa itu. Kedua, kata itu masih terasa asing oleh para pengguna bahasa asli, maka ejaan dan pengucapanya masih mengikuti cara asing pula. Ketiga, kata-kata yang berasal dan bahasa asing yang digunakan untuk kepentingan peristilahan, dan memperkaya kosa kata bahasa asli, kata-kata itu diterjemahkan ke dalam bahasa asli, penggunaan dan penulisannya disesuaikan dengan kaidah bahasa tersebut.

Pada dasarnya menyerap kata-kata dan bahasa asing untuk dijadikan bahasa resmi tidaklah bermasalah, selama proses penyerapan itu bisa diterima dan sesuai dengan kaidah yang ditentukan dalam proses penyerapan itu. Kemudian terdapat tiga tahap proses pembentukkannya, pertama, pencarian padanan kosa kata asing tersebut kedalam bahasa asli, kedua, jika tidak kunjung ditemukan padanan katanya, pencarian padanannya dalam bahasa-bahasa yang serumpun dan terakhir, jika masih belum dtemukan padanannya juga, barulah dilakukan penyerapan sepenuhnya, dengan terkadang menyesuaikan ejaannya dalam bahasa asli. Proses yang terakhir banyak ditemukan dalam penelitian ini. 
Kata-kata serapan bahasa Belanda dapat diteliti berdasarkan etimologi yaitu penyelidikan mengenai asal usul kata serta perubahan-perubahannya dalam bentuk dan makna (Kridaksana, H. Kamus Linguistik”, 2011) pada bahasa Melayu-Manado akan dikaitkan dengan penetitian ini yang merupakan salah satu aspek pengkajian leksikologi.

Leksikologi adalah suatu ilmu yang mengambil Ieksikon sebagai obyek: asahusulnya, bentuknya, pembentukannya, maknanya serta aspek bunyi dan ejannya. Istilah 'leksikon" lazim digunakan untuk mewadahi konsep "kumpulan 'leksem' dari satu bahasa, baik kumpulan secara keseluruhan maupun sebagian. Dalam bahasa Yunani kuno "leksikon" berarti 'kata, ucapan, cara bicara. 1stilah "Ieksikon" sepadan dengan "kosa kata", leksikon=nomina dan leksikal=ajektiva). Sedangkan "leksem" diartikan sebagai bentuk yang akan menurunkan sebuah ataupun sejumlah "kata", contoh: bentuk "write" (menulis) dalam bahasa lnggris, dapat diturunkan menjadi: "wrote, written, writes, writing, writer dan writers. Dengan kata lain "leksem" adalah kata dasar, kata gabungan, kata berimbuhan, kata ungkapan dan idiom. Oeh sebab itu penulis mengambil leksikologi sebagai kajiannya.

Bahasa Melayu-Manado, adalah obyek penelitian yang akan penulis kaji lebih lanjut, dituturkan penduduk di kota Manado, Bitung, Tomohon, kabupaten-kabupaten di Minahasa dan sekitarnya. Memiliki kesamaan dengan dialek bahasa di Sulawesi Tengah dan Maluku. Sebagian besar kata-kata dalam bahasa Melayu-Manado hampir sama dengan kata-kata dalam bahasa Indonesia, yang merupakan rumpun bahasa Melayu. Bahasa Melayu-Manado hanya digunakan untuk komunikasi lisan, tidak ada standar ortografi/tulisan yang pernah disahkan. Bahasa Melayu-Manado berhubungan dekat dengan bahasa Indonesia. Perbedaan yang paling mendasar adalah dengan adanya katakata serapan dari bahasa Belanda (dan bahasa Portugis). Bahkan jika dilakukan penelitian lebih mendalam, sebagian pembendaraan kata dalam bahasa Melayu-Manado diambil dan bahasa Indonesia dan Melayu, sebagiannya lagi dan bahasa Portugis, dan bagian terbesarnya diadopsi/diserap dan bahasa Belanda.

Penelitian ini dikaji secara leksikologi yang merupakan suatu bagian dalam ilmu linguistik yang mengambil leksikon sebagai obyek: asal usulnya, bentuknya, pembentukannya, maknanya serta aspek bunyi dan ejaannya.

Penelitian ini mengidentifikasikan bentuk-bentuk kata serapan bahasa Belanda ke dalam bahasa Melayu-Manado sehingga memperkaya perbendaharaan kata pada bahasa Melayu-Manado. 
Penelitian ini dapat memperkaya pengenalan kata-kata serapan bahasa asing, terutama bahasa Belanda ke dalam bahasa Melayu-Manado, sejarah Sulawesi Utara dalam berhubungan dengan kolonial Belanda pada masa kolonialisme (1608-Desember 1949) dan memperdalam kajian leksikologi dalam bidang linguistik.

Penelitian ini dapat pula membantu pasangan kawin campur antara warga negara Belanda dengan masyarakat Manado, untuk menguasai kedua bahasa tersebut dan segi penguasaan kata, dapat menjelaskan sejarahnya secara leksikologi dan penerapannya dalam kehidupan sehari-hari. Dapat pula digunakan dalam pengajaran bahasa di tingkat pendidikan tinggi.

Dalam melaksanakan penelitian, penulis mengkaji fokus dan masalah dengan menggunakan beberapa pendekatan. Pendekatan utamanya ialah pendekatan leksikologi, yaitu pendekatan yang mengambil leksikon sebagai obyeknya. Pendekatan lainnya seperti pendekatan linguistik, etimologi dan morfologis. Pendekatan linguistik artinya pendekatan yang digunakan penulis dalam menganalisis data bahasa yang dikumpulkan. Pendekatan etimologi artinya pendekatan sejarah mengenai asal-usul kata serta perubahanperubahannya dalam bentuk dan makna. Pendekatan morfologis digunakai untuk mengkaji bentuk, struktur dan makna kata.

\section{Kajian Teori dan Pembahasan}

Dalam buku "Encyclopaedie van Nederlandsch Indië”. Den Haag, 1939 tentang sejarah Sulawesi-Utara sebenarnya adalah sejarah Minahasa. Minahasa berarti persatuan atas ke-tujuh suku dibentuk pada abad ke - 15 dengan nama walak yaitu: Tombulu, Tonsea, Toulour, Tountemboan, Tounsawang, Ponosakan dan Ratahan. Pada abad ke-16, Spanyol mendarat (1574) dan menduduki Minahasa.

Tak lama setelah itu Belanda datang dan menduduki Minahasa (sejak tahun 1608). Pada tahun 1673, didirikan Benteng Amsterdam yang menjadi pusat kekuasaan Belanda di Maluku. Pada tahun 1979 Gubernur Maluku, Robert Padtbrugge menanda-tangani hubungan kerjasama yang merupakan langkah awal hubungan baik hingga lebih dan 300 tahun antara walak dengan pemenintahan Hindia-Belanda. Sempat terjadi pemberontakan kecil pula diantara walak dan pemerintahan Belanda (1807-1809). Setelah tahun 1809, akhir dan masa pemberontakan walak, Minahasa menjadi bagian dari pemerintahan Hindia-Belanda. Pada abad ke-19, meskipun di sebagian kecil daerah di Minahasa terjadi pula pemberontakan, namun Minahasa mendeklarasikan 'kesetiaannya' dengan pemerintah Hindia-Belanda. Banyak tentara Minahasa bergabung dengan kesatuan tentara Belanda 
yang bernama Koninklijk Nederlands Indisch Leger (KNIL) pada abad ke-20. KNIL tendiri dari sepertiga tentara Minahasa (tentara Indonesia sering meyebut mereka dengan istilah 'Anjing Belanda') dan dua per-tiga Iainnya adaiah tentara Belanda. Pada tahun 1947, pergerakkan politik yang menyebut “De Twaalfde Provincie (Profinsi ke-12)" menyatakan bahwa Minahasa ingin menjadi bagian dan negara Belanda. Keinginan ini dipelopori dengan sebuah perjanjian oleh seorang kristen Minahasa, Sam Ratulangi, yang pada saat itu menjabat sebagai seorang Gubernur Republik pertama di provinsi Indonesia timur (1946), dan Presiden Negara Indonesia Timur (State of East Indonesia) dijabat oleh Tjokorde Gde Rake Sukawati. Pada tahun 1957 pecah 'permesta' (Piagam Perjuangan Semesta). Pada tahun 1960 profinsi Sulawesi Utara dan Tengah terbentuk. Sejak tahun 1964 Sulawesi Tengah menjadi provinsi yang berdiri sendiri dan pada tahun 2001 Sulawesi Utara berpisah dengan provinsi Gorontalo.

Geoffrey Leech, dalam bukunya "Semantics" (1974) membedakan makna pada tujuh unsur yang berbeda yaitu sebagai berikut:

1. Makna konseptual yaitu makna yang menekankan pada makna logis. Kadang-kadang makna ini disebut "makna denotatif" atau "kognitif". Walaupun sesungguhnya ada kemungkinan terdapat perbedaan makna konseptual pada setiap diri pemakai bahasa, dapat diasumsikan bahwa makna konseptual adalah makna yang tertulis pada kamus. 2. Makna konotatif adalah nilai komunikatif dari suatu ungkapan menurut apa yang diacu. Contohnya: kata "woman" (wanita) dalam makna konseptualnya hanya berarti: manusia, bukan laki-laki dan dewasa. Namun dalam makna konotatif, terdapat sifat tambahan yang diacu, baik sifat fisik, psikis atau sosial, seperti contohnya makna konotasi kata "woman" bersifat psikis lemah, mudah menangis, penakut, dan lain sebagainya yang melekat pada kata "wanita" tersebut diatas.

3. Makna stilistika atau sering pula disebut makna sosial adalah makna sebuah kata yang menunjukkan lingkungan sosial penggunaannya. Adanya beberapa ucapan atau kata sebagai dialek, menunjukkan tentang asal-usul penutur menurut lingkungan geografis atau sosial. Makna ini pula menunjukkan sesuatu mengenai hubungan sosial antara penutur dan pendengarnya.

4. Makna afektif adalah makna yang mencerminkan perasaan pribadi penutur, termasuk sikapnya terhadap pendengar, atau sikapnya terhadap sesuatu yang dikatakannya.

5. Makna reflektif adalah makna yang timbul dalam hal makna konseptual ganda, jika suatu pengertian dari suatu kata pada pemakaiannya secara otomatis memunculkan sebagai 
respon kita terhadap pengertian lain. Makna ini sering pula dipahami sebagai sugesti yang terdapat pada suatu pemakaian bahasa.

6. Makna kolokatif adalah makna yang mengandung asosiasi-asosiasi yang diperoleh suatu kata, yang disebabkan oleh makna kata-kata lain yang cenderung muncul dalam lingkungannya. Makna reflektif, kolokatif, afektif, stilistik dan konotatif dapat disatukan kedalam suatu kategori besar, yaitu makna asosiatif.

7. Makna tematik adalah jenis yang terakhir, yaitu makna yang dikomunikasikan menurut cara penutur atau penulis menatap pesannya, dalam arti urutan, fokus dan penekanannya.

Penulis hanya menggunakan makna konseptual yaitu makna yang menekankan pada makna logis. Kadang-kadang makna ini disebut "makna denotatif" atau "kognitif". Walaupun sesungguhnya ada kemungkinan terdapat perbedaan makna konseptual pada setiap diri pemakai bahasa, dapat diasumsikan bahwa makna konseptual adalah makna yang tertulis pada kamus. Makna ini dipandang sebagai faktor yang signifikan dalam komunikasi bahasa, karena makna jenis ini mempunyai struktur yang kompleks dan rumit, yang dapat dianalisis pada struktur tataran bahasa fonologis, morfologis maupun sintaksis. Seperti struktur linguistik yang lain, makna ini juga tidak lepas dan prinsip-prinsip yang mengikutinya yaitu:

a) prinsip kontrastif, prinsip kontrastif adalah sebuah prinsip dalam menganalisis sebuah tataran bahasa dengan cara mencarikan lawan atau kontra dari tataran tersebut. Prinsip ini juga dilakukan dalam rangka mengidentifikasi fonem-fonem dalam sebuah bahasa. Namun dalam tahap menganalisis fonem digunakan cara dengan mencari pasangan minimalnya (minimal pairs), sehingga dengan pasangan minimal tersebut dapat kita katakan bahwa antara satu fonem dengan fonem lain itu berbeda karena memiliki perbedaan arti dan makna. Sebagai contoh: kata 'beri' dan 'peri'. Fonem /b/ dan /p/ merupakan 2 fonem yang berbeda ketika diikuti dengan ketiga fonem yang sama, karena memiliki arti secara leksikal berbeda. 'beri' memiliki arti 'menyerahkan, membagikan atau menyampaikan sesuatu, sementara 'peri' memiliki hal; sifat; keadaan, curah hujan yang lebat dan mendadak, untuk perempuan yang elok rupanya (dalam KBBI). Selain itu makna konseptual juga dapat dilihat dan ciri-ciri penandanya. Prinsip ini jug digunakan untuk mengidentifikasi makna konseptual sesuatu bahasa.

b) Prinsip struktur konstituen, prinsip ini menggambarkan bahwa unit-unit bahasa yang lebih besar tersusun dari unit-unit bahasa yang lebih kecil atau dengan kata lain tersusun dan immediate constituent hingga ultimate constituent. 
Penelitian ini secara morfologis meneliti kata-kata berkaitan erat dengan makna konseptualnya secara leksikal baik dalam bahasa Melayu-Manado maupun dalam bahasa Belanda, seperti yang akan diuraikan dibawah ini.

Putrayasa dalam bukunya "Kajian Morfologi" (2008) mengidentifikasi kelas kata yang ada dalam bahasa Indonesia sebagai berikut:

1. Verba (kata kerja) adalah kata yang menyatakan tindakan.

\begin{tabular}{|c|c|c|}
\hline $\begin{array}{l}\text { Bahasa Melayu- } \\
\text { Manado }\end{array}$ & $\begin{array}{lll}\text { Serapan dan } & \text { Bahasa } \\
\text { Belanda } & & \\
\end{array}$ & $\begin{array}{l}\text { Makna dalam bahasa } \\
\text { Indonesia baku }\end{array}$ \\
\hline skop[skop] & schoppen[s $k$ ho $p$ e $n$ ] & tendang \\
\hline (ba)-straf[s $t r a f]$ & straffen [s $t$ rafe $n]$ & $\begin{array}{l}\text { menghukum dengan berdiri di } \\
\text { depan kelas. }\end{array}$ \\
\hline$(b a)-k l a k[k l a ?]$ & klagen [k la he $n$ ] & mengadu \\
\hline$(b a)-\operatorname{trap}[t r a p]$ & 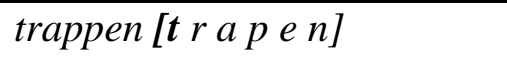 & mengayuh \\
\hline (ba)-tap [t a p] & tappen [t a $p$ e $\quad n]$ & menampung (zat cair) \\
\hline (ba)-skor [s k or $r]$ & schoren [s $k$ orren] & menilai \\
\hline $\operatorname{spul[sp}$ u l] & spoelen [s p u le $\quad$ ] ] & membilas (dengan air) \\
\hline prop [p ro p] & proppen [p r o p e $n$ ] & menyumbat, menghambat \\
\hline$(b a)$-rem [ $\left[\begin{array}{lll}r & \varepsilon & m\end{array}\right]$ & remmen $\left[\begin{array}{lllll}r & \varepsilon & m & e & n\end{array}\right]$ & mengerem (kendaraan) \\
\hline (ba)-lem [le $\mathrm{m}]$ & lymen $\left[\begin{array}{lllll}1 & \varepsilon & m & e & n]\end{array}\right.$ & merekatkan, mengelem \\
\hline (ba)-dansa[da $n$ s a $]$ & dansen [d $a$ n $\left.\begin{array}{llll} & e & n\end{array}\right]$ & menari, berdansa \\
\hline teken $\left[\begin{array}{lllll}t & k & \varepsilon & n]\end{array}\right.$ & $\begin{array}{l}\text { (heend)-tekenen [t } \varepsilon k \text { e } n e \\
n]\end{array}$ & menanda-tangani \\
\hline (ba)-stir[stir] & sturen [sture $n]$ & mengendarai (kendaraan) \\
\hline (ba)-betel [b c $t$ \& l] & bytelen $\left[\begin{array}{l}b \varepsilon \mathrm{t} e \\
e\end{array}\right.$ & mengukir kayu/beton \\
\hline$(b a)-b e l\left[\begin{array}{lll}b & \varepsilon & 1\end{array}\right]$ & opbellen[o $p$ b $\varepsilon$ I $\quad$ e $n]$ & menelefon \\
\hline beslag[be s I a h] & beslag leggen[b e s la $h]$ & menyita, mengadon \\
\hline$(\mathrm{ba})-\operatorname{stel}[\mathrm{s} t \mathrm{t} \varepsilon \mathrm{l}]$ & (af)-stellen [s $t$ \& $I$ e $\quad n]$ & bergaya \\
\hline$(b a)$-sto [s to $\quad r]$ & storten[s to r te $n$ ] & menyetor (uang) \\
\hline$(b a)-s t o t[s t o t]$ & stoten $[s$ to $t$ e $n]$ & gerakan awal yang cepat \\
\hline spoit [s poitJ & spuiten[s p o it e $n$ ] & menyemprot \\
\hline $\begin{array}{l}\text { andenzuuk [anderz } \\
u \text { '] }\end{array}$ & $\begin{array}{l}\text { onderzoeken[a nderzuke } \\
n]\end{array}$ & menginterogasi \\
\hline
\end{tabular}




\begin{tabular}{|c|c|c|}
\hline (ba)-spik [s p i’] & spieken[s pike $n$ ] & menyontek \\
\hline flao $\left[\begin{array}{llll}a & o\end{array}\right]$ & flauw valen [f l a o] & jatuh pingsan \\
\hline (ba)-grut [hrut] & Groeten[hrute $n$ ] & menyapa, mengajak turun dansa \\
\hline$p u p\left[p u^{\prime}\right]$ & poepen [p и p e $n]$ & membuang air besar \\
\hline (ba)-Iap [lap] & lappen (roam) [l a p e $n]$ & menyeka, mengelap \\
\hline (ba)-infal[ $\mathrm{i}$ nf a l] & inval[infal] & mengisi jam pelajaran yang kosong \\
\hline makion [m a $k$ lo $\quad$ u $n$ ] & $\begin{array}{l}\text { maakloon(maken) [m a klo } \\
\text { u n] }\end{array}$ & $\begin{array}{l}\text { mengerjakan pesanan (jahitan } \\
\text { pakaian, dll) }\end{array}$ \\
\hline snap [s $n$ a p] & snappen[s $n$ a $p$ e $n$ ] & mengerti \\
\hline $\begin{array}{l}(b a) \text {-plester }\left[\begin{array}{lll}p l & \varepsilon & s t \\
\varepsilon & r]\end{array}\right.\end{array}$ & pleisteren $[p$ l c s t e r e $n]$ & memplester \\
\hline (ba)-sous [s o u s] & saus maken [ [s o $\begin{array}{lll}s & \text { s] }\end{array}$ & membuat saus (lauk) \\
\hline rest $[r e s t]$ & rusten[reste $n]$ & beristirahat \\
\hline $\operatorname{reken}\left[\begin{array}{lllll}r & \varepsilon & k & \varepsilon & n\end{array}\right]$ & rekenen $\left[\begin{array}{r}r \\
\varepsilon\end{array}\right.$ e e $n$ e $\left.n\right]$ & menghitung \\
\hline
\end{tabular}

Hampir seluruh bahasa di Indonesia tidak memiliki susunan sebuah kata yang terdiri dari:
Kata:
C
C
C

Seperti dalam,

schoppen:

schoren:

bytelen:

b

y

$t$

schaven: $s c h a$

Sehingga penulisan dan pelafalannya sesuai dengan yang didengar, sch-menjadi 'sk'dan by-menjadi 'be'.

Menurut Hyman (1975) dalam bukunya "Phonology Theory and Analysis" menjelaskan perubahan bahasa maksud yang relatif kompleks dari bunyi ujaran tertentu melebihi lainnya memainkan peranan yang sangat penting dalam menentukan arah perubahan bunyi. Walaupun terkenal faktanya bahwa bunyi berubah seturut perubahan waktu, sebagai contoh dalam bahasa Melayu-Manado berabad-abad yang lalu menggunakan bahasa Belanda untuk mengucapkan kata [buurman] berubah menjadi [birman] 'tetangga' saat sekarang, berhubung mereka tidak memiliki bunyi [U], beberapa perubahan bunyi lebih sering ditemui dalam suatu bahasa dan pada yang lainnya, 
sementara masih ada perubahan bunyi potensial lainnya tidak dipakai sama sekali, sebagai contoh, dalam bahasa Indonesia ada beberapa kata-kata pinjaman/kata-kata asing, tetapi beberapa diantaranya sama sekali tidak digunakan.

Ilmu yang mempelajari perubahan bunyi berkaitan erat dengan ilmu universal implikasi dan akusisi bahasa. Penekanan bunyi-bunyi yang drop/hilang di akhir kata lebih banyak ditemukan dan pada diawal kata, biasa disebut "historically lost", sebagai contoh, dalam Bahasa Melayu-Manado [s k o p] berasal dan Bahasa Belanda "schoppen” [skopen] dimana bunyl akhirnya —an hilang secara historis.

Dari tabel verba diatas, dapat dilihat bahwa seluruh verba dalam bahasa Belanda berakhiran dengan — en. Ternyata dan kenyataan psikologis terjadi “historically lost” yaitu penekanan bunyi-bunyi yang drop atau hilang diakhir kata (Iebih banyak ditemukan dan pada diawal kata).

Mangulu, M. S. D (2002) menulis bahasa Melayu-Manado berfrekuensi terbesar adalah kata yang ber-prefiks/benawalan 'ba-'. Pada tabel, bahasa Melayu-Manado menyerap kata-kata dan bahasa Belanda sebagai kata dasar dan menggunakan prefiks 'ba-' untuk membentuk verba.

2 Nomina (kata benda) adalah kata yang mengacu pada manusia, binatang, benda dan konsep atau pengertian.

\begin{tabular}{|c|c|c|}
\hline Bahasa Melayu-Manado & $\begin{array}{l}\text { Serapan dari Bahasa } \\
\text { Belanda }\end{array}$ & Bahasa Indonesia baku \\
\hline brot (goreng)[brot] & brood [brot] & Roti \\
\hline oto[o to & auto [o to] & kendaraan mobil \\
\hline kran[kran] & kraan[kran] & keran air \\
\hline mok[m o'] & mok[m o’] & cangkir \\
\hline$k a s[k a s]$ & kast [k $a$ s] & lemari penyimpan \\
\hline veref[lver $\quad r$ ef] & verv[veref] & Pensil warna, pewarna, crayon \\
\hline reklame $\left[\begin{array}{r}r \\
\varepsilon\end{array}\right.$ l a $\left.m \boldsymbol{e}\right]$ & reclame [r $\mathbf{E} k$ la $m e]$ & iklan \\
\hline tegel[t \& he l] & tegel[te he l] & ubin \\
\hline stif[s t if] & stuff [s $t$ iff] & karet penghapus \\
\hline krans [krans] & krans [krans] & karangan bunga duka \\
\hline hanskun [ha $n$ s $k u n$ ] & $\begin{array}{l}\text { handschoen [ha } n \text { s } s k u \\
n]\end{array}$ & sarung tangan \\
\hline forok [ [ $\begin{array}{llll}\text { o } & \text { r o'] }\end{array}$ & vork [vore'] & garpu \\
\hline
\end{tabular}




\begin{tabular}{|c|c|c|}
\hline leper $[l \varepsilon p \varepsilon r]$ & lepel[l c p e l] & sendok \\
\hline$h u k\left[h \quad u^{\prime}\right]$ & hoek[hu'] & sudut \\
\hline rosbang [ros $\left.\begin{array}{lll}r & a & \pi\end{array}\right]$ & rust bank [ros $\quad$ b a $\pi]$ & dipan \\
\hline $\operatorname{sak}\left[s a^{\prime}\right]$ & $z a k\left[s a^{\prime}\right]$ & karung \\
\hline stat $[s t a t]$ & $\operatorname{stad}\left[\begin{array}{lll}\mathrm{t} & a & t\end{array}\right]$ & (di dalam) kota \\
\hline blek[ble'] & blik[ble'] & Kaleng \\
\hline dop $[d o p]$ & dop [d op] & penyumbat \\
\hline benen $l b \quad \varepsilon \quad n \quad \varepsilon \quad n]$ & binnen (band)[b e $n$ e $n]$ & ban dalam, pelampung \\
\hline frak [fra'] & vracht [fra'] & sesuatu untuk transpor \\
\hline rets[rets] & rits[rets] & retsleting \\
\hline knop [k $n$ o $p]$ & Knop $[k n o p]$ & kancing (baju), tombol \\
\hline 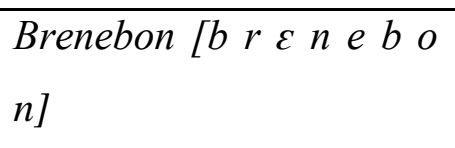 & $\begin{array}{l}\text { breneboon }\left[\begin{array}{l}b \\
\varepsilon\end{array} \text { e } b o\right. \\
n]\end{array}$ & kacang merah \\
\hline wayer [w a y e r & waaier [w a ye r] & kipas angin \\
\hline blende [b l e e $n d e$ e] & blende darm [b l c $\mathrm{E} n d e]$ & usus bntu \\
\hline paal [p a l] & paal [p a l] & tiang \\
\hline bete [b e t e] & biet [bet] & talas \\
\hline birman [b I $r$ m $a$ a $]$ & buurman lb I r $m$ a $a$ ] & tetangga \\
\hline kukis[kukis] & koekjes [k u kis] & kue \\
\hline panekuk[p a n e $k$ u '] & pannekoek[p a n e $k u$ ?] & pancake, sejenis kue \\
\hline opa $\left[\begin{array}{lll}o & p & a\end{array}\right]$ & opa[o $p$ a $]$ & kakek \\
\hline oma[o $m$ ma & oma[o $\mathrm{m}$ a $]$ & nenek \\
\hline om $[\mathrm{o} \mathrm{m}]$ & oom [o m] & paman \\
\hline tante[t a $n$ te] & tante[t a $n$ t e] & bibi \\
\hline papa [p $a$ p $a]$ & papa[p $а$ a $p$ a $]$ & ayah \\
\hline mama [m a $m a]$ & mama [ma $m$ a & ibu \\
\hline prong [p r $\quad$ o $\boldsymbol{\eta}]$ & $\operatorname{pronk}\left[\begin{array}{llll}p & \text { r } & o & \eta\end{array}\right]$ & hiasan \\
\hline sermes $[s \in r \quad m \varepsilon s]$ & scheermes[s $\boldsymbol{\varepsilon} r m \boldsymbol{\varepsilon} \boldsymbol{s}]$ & silet \\
\hline bundur [b u $n d \quad u r]$ & boender[bu $n$ de $r]$ & sikat \\
\hline kanikir [kanikir] & knikker [knikir] & kelereng \\
\hline falinggir [vali $\eta$ ir] & vlienger $[v l \eta g e r]$ & Iayang-Iayang \\
\hline
\end{tabular}




\begin{tabular}{|c|c|c|}
\hline vakansi[va $k$ a $n$ s i] & vakantie [va & liburan \\
\hline klat[klat] & klad [klat] & pola \\
\hline slot [ $\left[\begin{array}{lll}\mathrm{s} & \mathrm{o} & \mathrm{t}\end{array}\right]$ & slot [s lo t] & gembokan, kunci \\
\hline Sipat[s i pat] & zijpad [s i p a t] & batas antar tanah miik \\
\hline pace [pace] & paatj [par $a c e$ ] & bapak,tuan \\
\hline mace [ma $\quad$ c e e] & maatje[m a c e] & Ibu, nyonya \\
\hline broit [broit] & bruid [broit] & pengantin perempuan \\
\hline $\begin{array}{l}\text { bredegom }[b r \varepsilon d e g o \\
m]\end{array}$ & 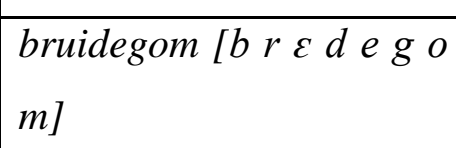 & pengantin laki-laki \\
\hline $\begin{array}{l}\text { broit meses [b ro it } m \varepsilon \\
\text { ses] }\end{array}$ & $\begin{array}{l}\text { bruidsmeisjes [b r o I } t \mathrm{~m} \\
\left.\varepsilon \begin{array}{lll}\mathrm{e} & \mathrm{s}\end{array}\right]\end{array}$ & pagar ayu \\
\hline klom [klo $\mathrm{l}$ ] & klomp [k I o m] & sendal/sepatu kayu \\
\hline koi $[k o i]$ & kooi [ko ii] & ternpat tidur \\
\hline budel [b u d e l] & boedel [b u de l] & warisan/harta gono-gini \\
\hline afdrek[afdre'] & afdruk[afdre'] & afdruk untuk foto \\
\hline balak[b a l a '] & balk[b a l a '] & balok(kayu) \\
\hline latah [I a t a h] & lat [lat $h]$ & $\begin{array}{l}\text { balok }\{\text { kayu }\} \text { panjang berukuran kecil } \\
(2 \times 3 \mathrm{~cm})\end{array}$ \\
\hline $\operatorname{das}[d a s]$ & $\operatorname{das}[d a s]$ & dasi \\
\hline jas $[j a s]$ & jas[y $a s]$ & pakaian resmi [jenis jas] \\
\hline eis [e is] & $i j s[e i s]$ & es \\
\hline 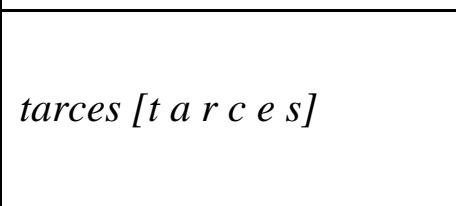 & taartjes [t a r c e e s] & $\begin{array}{l}\text { kue mentega tart ukuran kecil } \\
\text { (biasanya dihidangkan pada acara } \\
\text { perkawinan) }\end{array}$ \\
\hline
\end{tabular}

Permainan kartu remi, beserta nama-nama kartunya dalam bahasa Melayu-Manado menyerap penuh dan bahasa Belanda. Berikut daftar permainan kartu remi;

\begin{tabular}{|l|l|l|}
\hline bur & boer & kartu 'Jack'/J \\
\hline vrouw & vrouw & kartu 'Queen'/ratu \\
\hline koncng & koning & kartu 'King'/K \\
\hline skopong & schoppen & kartu skop/pohon \\
\hline roitcn & ruiten & kartu wajik \\
\hline
\end{tabular}




\begin{tabular}{|l|l|l|}
\hline hartEn & harten & kartu 'Iove'/buah hati \\
\hline klawar & claver & kartu keriting \\
\hline
\end{tabular}

Sedemikian banyaknya nomina dalam bahasa Melayu-Manado hasil serapan dari bahasa Belanda yang penulis akan sebutkan keseluruhannya sebagai data penelitian selanjutnya. Nomina adalah jenis kelas kata terbanyak dalam bahasa Melayu-Manado hasil adopsi/serapan dari bahasa Belanda. Inilah yang membuat setengah pembendaharaan kata dalam bahasa Melayu-Manado adalah merupakan hasil adopsi dari bahasa Belanda.

Bahasa Melayu-Manado hanya digunakan untuk komunikasi lisan, sehingga tidak ada standar ortografi/tulisan yang pernah disahkan. Jika dilihat dan bentuk nomina diatas, tufisan/ortografilah yang membedakan antara nomina bahasa Melayu-Manado dengan bahasa Belanda, tetapi bunyi pelafalannya sama.

3. Adjektiva (kata sifat) adalah kata yang memberikan keterangan yang lebih khusus tentang sesuatu yang dinyatakan dalam kalimat, contoh ajektiva;

\begin{tabular}{|c|c|c|}
\hline Bahasa Melayu-Manado & $\begin{array}{l}\text { Serapan dan Bahasa } \\
\text { Bela nda }\end{array}$ & Bahasa Indonesia baku \\
\hline afker $[a f k \varepsilon r]$ & afkeur[afk\&r] & tidak berguna \\
\hline blao $\left[\begin{array}{lllll}a & o\end{array}\right]$ & blauw [b la o] & biru \\
\hline $\operatorname{span}\left[\begin{array}{lll}s & p & a\end{array}\right]$ & spann [s pa $a$ ] & ketat \\
\hline dongker[do $\eta$ ker] & donker[d on k e r] & warna gelap, seteri biru tua \\
\hline grap [grap] & $\operatorname{grap}[g r a p]$ & bersifat lucu \\
\hline$m o i\left[\begin{array}{lll}m & o & i\end{array}\right]$ & mooi [m & cantik, menawan \\
\hline pars $\left[\begin{array}{lll}p & a & r\end{array}\right]$ & paars [p a $r s]$ & ungu \\
\hline smal [s $\begin{array}{lll}\text { m } & a & I]\end{array}$ & 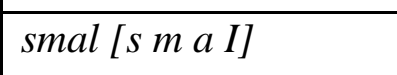 & kecil \\
\hline $\operatorname{gros}[g r o s]$ & $\operatorname{groot}[\mathrm{g} r \mathrm{ot}]$ & besar \\
\hline fol[foll] & $\operatorname{vol}\left[\begin{array}{lll}v & o & l\end{array}\right]$ & penuh \\
\hline bludeng [b l u $d \varepsilon \boldsymbol{\varepsilon} \boldsymbol{\eta}]$ & bloeding [b l u $d \boldsymbol{\varepsilon} \boldsymbol{\eta}]$ & berdarah \\
\hline Jelus[j el $\mathrm{u} s$ s] & jalous [j e l u s] & cemburu \\
\hline (idong) plat [p I a t] & plot [p I $\quad$ a t] & datar, pesek \\
\hline $\operatorname{slak}\left[s\right.$ l $\left.a^{\prime}\right]$ & slag [s l l $a^{\prime}$ '] & ada celah \\
\hline sombar [s o $\left.\begin{array}{lllll} & b & a & r\end{array}\right]$ & somber [s o mber] & teduh \\
\hline krol[krol] & kruil[krol] & keriting \\
\hline streng [ $\left[\begin{array}{llll} & r & \varepsilon & \eta\end{array}\right]$ & streng [str $\quad \varepsilon \eta]$ & tegas \\
\hline
\end{tabular}




\begin{tabular}{|c|c|c|}
\hline 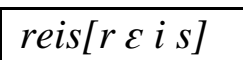 & rijst[reis] & mengembang \\
\hline blas [bllas] & blaas [b la s] & luka lecet akibat terbakar, lecet di tubuh \\
\hline
\end{tabular}

Adverbia (kata keterangan) adalah kata yang ciapat mendampingi adjektiva,

numeralia, atau proposisi dalam konstruksi sintaksis.

Contoh adverbia yang menerangkan tempat:

1. Torang dudu sama-sama di place.

Bahasa Belanda: plaatsje [p l a c e].

2. Ana-ana bajalang kaki di trotoar.

Bahasa Belanda: trotoir [t r o t o a r].

3. Encik straf Aldo di depan klas.

Bahasa Belanda: straaf [s traf] dan klaas[k la s].

4. Dorang dudu bacirita didalang bes.

Bahasa Bela nda: bus [b e s\}.

5. Nanti torang baku dapa di sentrum.

Bahasa Belanda: centrum [s e n tru $\mathrm{ml}$.

6. Dia datang ka kampus so lat.

Bahasa Belanda: zo lat [s o I a t ].

Tidak terlalu banyak adverbia bahasa Melayu-Manado yang ditemukan sebagai hasil serapan dan bahasa Belanda.

5 Kata Tugas yang terdiri dari:

5.1 Preposisi (kata depan), contohnya:

- Kadow ini for ngana. Bahasa Belanda voor [v o r].

5.2 Konjungtor (kata sambung)

- $\quad$ Kita enda punya beras mar punya kentang.

Bahasa Belanda: maar[m a rJ.

- Karna torang enda punya beras dus torang harus makan

kentang.

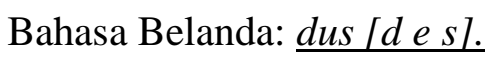

5.3 Partikel penegas

- So mangarti, toh?

Bahasa Belanda: toch? [t o h]?

5.4 Artikula 
Bahasa Melayu-Manado tidak dijumpai artikula sebagai hasil serapan dari bahasa Belanda. Dikarenakan penamaan gelar diambil langsung (warisan) dan leluhur Minahasa. Sedangkan artikula yang mengacu ke makna kelompok hanyalah dengan mereduplikasi kata tersebut. Bahasa Melayu-Manado juga terdapat banyak/berfrekuensi terbesar dalam proses reduplikasi kata.

5.5 lnterjeksi

- BahI So badusta dia.

Bahasa Belanda: Bah! [b a h]

- Au! Saki ta pe luka.

Bahasa Belanda: $\underline{A u ![a ~ u\rceil}$

- Dorang ba Hura!

\section{Bahasa Belanda: Hoera! [h u r a]}

Bagian yang telah disebutkan diatas meyakinkan penulis bahwa hampir seluruh kata serapan bahasa Belanda kedalam bahasa Melayu Manado memiliki arti/makna yang sama dalam kedua bahasa tersebut, yang membedakan hanyalah tulisan/ortografi-nya saja.

Namun dalam penelitian ini dijumpai pula, beberapa kata yang sama pelafalannya, namun memiliki arti yang berbeda, seperti yang ditunjukkan pada tabel berikut:

\begin{tabular}{|c|c|}
\hline Bahasa Melayu-Manado & Serapan dan Bahasa Belanda \\
\hline (ba)-trap 'mengayuh, naik' & trap 'jalan bertingkat' \\
\hline neh 'partikel' & nee 'tidak' \\
\hline (ba)-stir 'mengendarai (kendaraan)' & $\begin{array}{l}\text { stâren 'mengirimkan urituk melakukan } \\
\text { sesuatu' }\end{array}$ \\
\hline koas 'kuas cat' & kwast 'orang bodoh' \\
\hline kil 'tempat tidur' & kooi 'sangkar hewan' \\
\hline kol 'sayur kubis' & kool 'batu perapian' \\
\hline mace 'ibu' & maatje 'geias pengukur' \\
\hline peip 'kehilangan, bangkrut' & puep 'pipa, pipa rokok' \\
\hline streng 'tegas' & streng 'segulung benang jahit' \\
\hline mantel 'baju hangat' & $\begin{array}{l}\text { mantel 'bahan pembungkus kawat pengalir } \\
\text { listrik' }\end{array}$ \\
\hline verban 'pembungkus luka' & $\begin{array}{l}\text { verband 'bahan penghubung sudut } \\
\text { perabotan kayu' }\end{array}$ \\
\hline
\end{tabular}




\begin{tabular}{|l|l|}
\hline reip 'mekar' & riep 'kondensasi zat beku cair' \\
\hline reis 'mengembang' & rijst 'naik ke atas' \\
\hline hol lubang' & hol 'kosong, sarang hewan dibawah tanah' \\
\hline $\begin{array}{l}\text { regel 'pegangan yang menempel di } \\
\text { bangunan' }\end{array}$ & regel 'baris dalam kalimat, peraturan' \\
\hline $\begin{array}{l}\text { in de kost 'menyewa kamar' } \\
\text { afdrek 'gaya/penarnpilan yang kaku sampai } \\
\text { berlebih }\end{array}$ & afdruk 'afdruk pada foto' \\
\hline
\end{tabular}

\section{Simpulan}

Sejarah membuktikan bahwa terjalin hubungan yang baik antara pemerintahan Hindia-Belanda dengan rakyat Sulawesi-Utara, yang pada saat itu dikenal sebagai Minahasa, yang juga merupakan provinsi ke-12 Belanda.

Kelas kata nomina menunjukkan frekuensi terbanyak kata bahasa Melayu-Manado hasil serapan dari bahasa Belanda. Terjadi historically lost akhiran ' - en' pada verba bahasa Belanda dalam bahasa Melayu-Manado. Kelas kata lainnya menunjukkan bahwa ada perbedaan tulisan/ortografi antara bahasa Melayu-Manado dengan bahasa Belanda, namun persamaan pengucapan kata yang diutamakan.

Terdapat persamaan makna konseptual antara dua kata yang sama pelafalannya antara bahasa Melayu-Manado dengan bahasa Belanda, namun ada pula yang berbeda makna antara dua kata yang sama pelafalannya.

\section{Daftar Pustaka}

Atkins, S., \& Rundel, M. 2008. The Oxford Guide to Practical Lexicography. Oxford: Oxford University Press.

Badudu, J. S. 2004. Kamus Kata-Kata Serapan Asing dalam Bahasa Indonesia, Jakarta: Penerbit buku "Kompas".

Bawa, I. W dan Cika, I. W. 2004. Bahasa dalam Perspektif Kebudayaan. Bali: Universitas Udayana.

Chaer, Abdul. 2001. Tata Bahasa Praktis Bahasa Indonesia. Jakarta: Rineka Cipta.

Chaer, A. 2007. Leksikologi\& Leksikografi Indonesia. Jakarta: Rineka Cipta.

Coulmas, F. 2003. Writing Systems: An Introduction to their linguistic Analysis. United Kingdom: Cambridge University Press.

Cruse, Alan. 2000. "Meaning in Language:" An Introduction to Semantics and 
Pragmatics. New York: Oxford University Press.

Duranti, Alesandro. 2003. Text book in “LinguisticAntropology”. United Kingdom:

Cambridge University Press.

Leech, Geoffrey. 1974. Semantics. Suffolk: Richard Clay (The Chaucer Press) Ltd.

Honthorst, A. dan Novia, W. 2010. Praktische Woordenboek. Jakarta: Kashiko Publisher.

Hyman, L. M. 1975. Phonology: Theory and Analysis. U S A: Holt, Rinehart and Winston. Keraf, Gorys. 1991. Tata Bahasa Indonesia. Jakarta: Universitas Indonesia.

Kridalaksana, H. 2011. Kamus Linguistik: Edisi Keempat. Jakarta: P T Gramedia.

Kurnia, N. S. 2007. Pemanfaatan Korpus dalam Pengajaran dan Pemelajaran Bahasa.

PELBBA 18: Pertemuan Linguistik PusaI Kajian Bahasa dan Budaya Atma Jaya. Jakarta: Yayasan Obor Indonesia.

Lauder, A. (2010). Data for lexicography: the central role of the corpus (prepublication draft). Wacana.

Mahsun. 2011. Metode Penelitian Bahasa: Tahapan strategi, metode dan tekniknya. Jakarta: Rajawali Pers.

Morris, Charles, W. 1946. Signs, Language, and Behavior. New York: Prentice Hall, USA.

Palmer, Richard E. 2005. Hermeneutika 'Teori Baru mengenai Interpretasi (diterjemahkan oleh Masnur Hery). Yogyakarta: Pustaka Pelajar.

Putrayasa, I. B. 2010. Kajian Morfologi (bentuk Derivasional dan lnfleksional). Bandung: P T Refika Aditama.

Schatz, H. F. 1986. PIat Amsterdams in its Social Context: A Sociolinguistic study of the dialect of Amsterdam. Amsterdam: P.J Meertens-lnstituut.

Setia, E. (2005). Semantik dan Leksikografi dalam Perkamusan. ENGLONESIAN: Jurnal llmiah Linguistik dan Sastra, Vol. 1 No. 1.

Sugihastuti. 2003. Bahasa Indonesia untuk Awam, Mahasiswa Dan Wartawan. Yogyakarta. Gama Media.

UlIman, S. 2007. Pengantar Semantik. Yogyakarta: Pustaka Pelalar.

Watuseke, F. 1992. In: Bijdragen tot de Taal-, Land- en Volkenkunde. Leiden: Leiden University.

Weissberg, R and Buker, S. 1990. Writing Up Research: experimental Research Report Writing for English Student. New Jersey: Prentice Hall, Inc.

Widjono Hs. 2007. Bahasa Indonesia, Mata Kuliah Pengmbangan Kepribadian Di perguruan Tinggi. Jakarta. PT Grasindo.

Wikipedia. 2012. Encyclopaedie van Nederlandsch Indië. Den Haag, 1939 . 